\title{
Vlad EFTENIE
}

\section{Parcul Carol - un posibil drum inițiatic al}

eroului interior. Pierdere și regăsire de sine

Am descoperit târziu aleile Parcului Carol.

Obișnuiam să mă deplasez aproape exclusiv de la vest spre centrul orașului. Eram poate obișnuit cu traseele circulare, puțin sinuoase, ale Cișmigiului sau, cu un zâmbet, desigur, ale parcului copilăriei, Drumul Taberei. Nu am avut drum aici decât foarte târziu, și nu mă refer la vreo oră din toiul nopții.

Un spirit explorator m-a îndemnat să cercetez locuri din București, în căutare de noi peisaje urbane și subiecte foto, cu câțiva ani în urmă.

Și totuși, „Carol” nu a fost o destinație de-sinestătătoare decât recent.

De ce povestesc toate acestea?

Pentru că stabilirea unei relatii aduce cu sine dialogul, iar dialogul e în măsură să deschidă calea unei înțelegeri, a unui posibil atașament. Îți poate păsa de ceva ce cunoști, te poți atașa de ceva care înseamnă ceva pentru tine. Așa cum eroul arhetipal trece prin diferite probe doar după ce inițiază un drum, în urma unei chemări invizibile, drum care îl poartă pe nenumărate tarâmuri care îl ajută să își afle adevărata fortă și identitate. Aflăm oare eroi în parcul Carol? Putem vorbi despre acest tărâm ca despre unul inițiatic? Cred că putem afla argumente suficiente în favoarea acestor idei, încât ceea ce risca să fie o succesiune anostă de idei, poate căpăta o scânteie neașteptată.

„Carol” nu seamănă cu celelalte parcuri din București. Deși fiecare are un „ceva” al lui, atrăgător și definitoriu, aici am intuit încă dintr-un început existența unui mister care aștepta să fie descifrat.

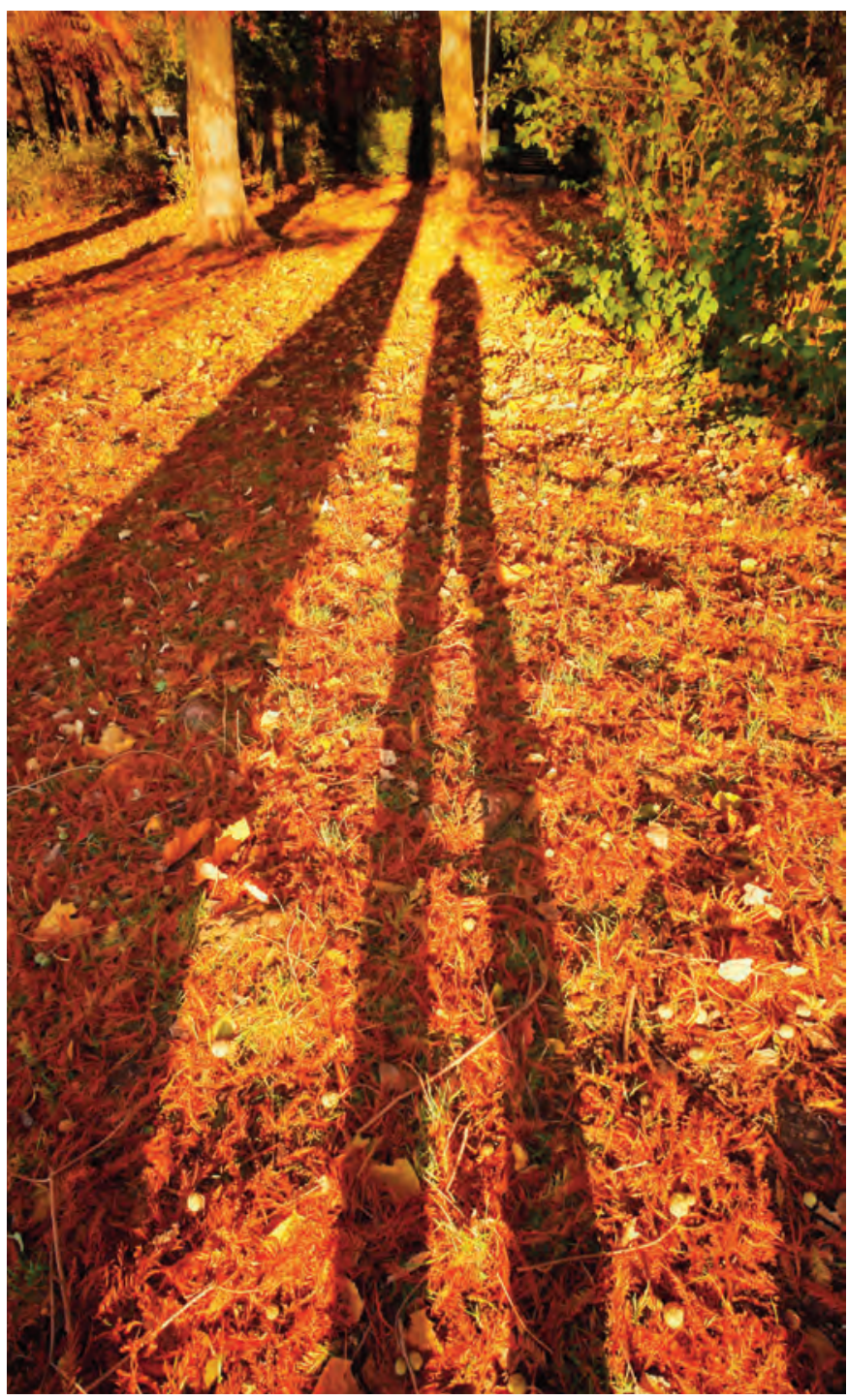


Memoria eroilor se odihnește aici și rămâne vie în lumina flăcării eterne. Mausoleul din capătul sudic străjuiește silueta orașului, oferind traseului un punct de reper. Intrarea de pe latura nordică este primitoare, un ax major se deschide ca o invitație de a porni la drum. Un drum foarte drept. Printre arborii care aparțin unei adevărate păduri - ieșirea din lumea cunoscută. Podul care se deschide peste luciul apei reprezintă simbolic o trecere spre un alt tărâm.

Pachetul de trepte monumentale ce precede Mausoleul conferă senzația unei viitoare provocări, a unei adevărate probe inițiatice, cu rol de transformare, ascensional. Înaintând pe acest traseu, pietonul, transformat pe neașteptate într-un erou mitologic, parcurge etape. Prin conștientizare și acceptare a jocului, spațiul se deschide, apa și cerul comunică, aerul se mișcă, arborii vibrează și spun mesaje neînțelese încă, se deschide o lume nouă. Privirea capătă încredere, pasul capătă apăsare. Axul central reprezintă simbolul drumului celui mai scurt spre îndeplinirea destinului. Urcând treptele, eroul lasă în urmă trecutul și poate apărea un dialog cu un sine latent, tăcut până atunci. Un ecou uitat sau încă neaflat. O perspectivă nouă se deschide astfel, pentru că lucrurile nu sunt niciodată doar ceea ce par. Ceea ce este mai profund, mai valoros, nu poate fi văzut, ci doar simțit, intuit, inițiat spre căpătarea unei substanțe palpabile doar având credința că ceva bun poate avea loc, oricând, la fiecare pas, chiar și la răscruce de tăceri și aparente absențe.

Există însă alternative.

Știm că drumul cel mai drept este și cel mai scurt, și

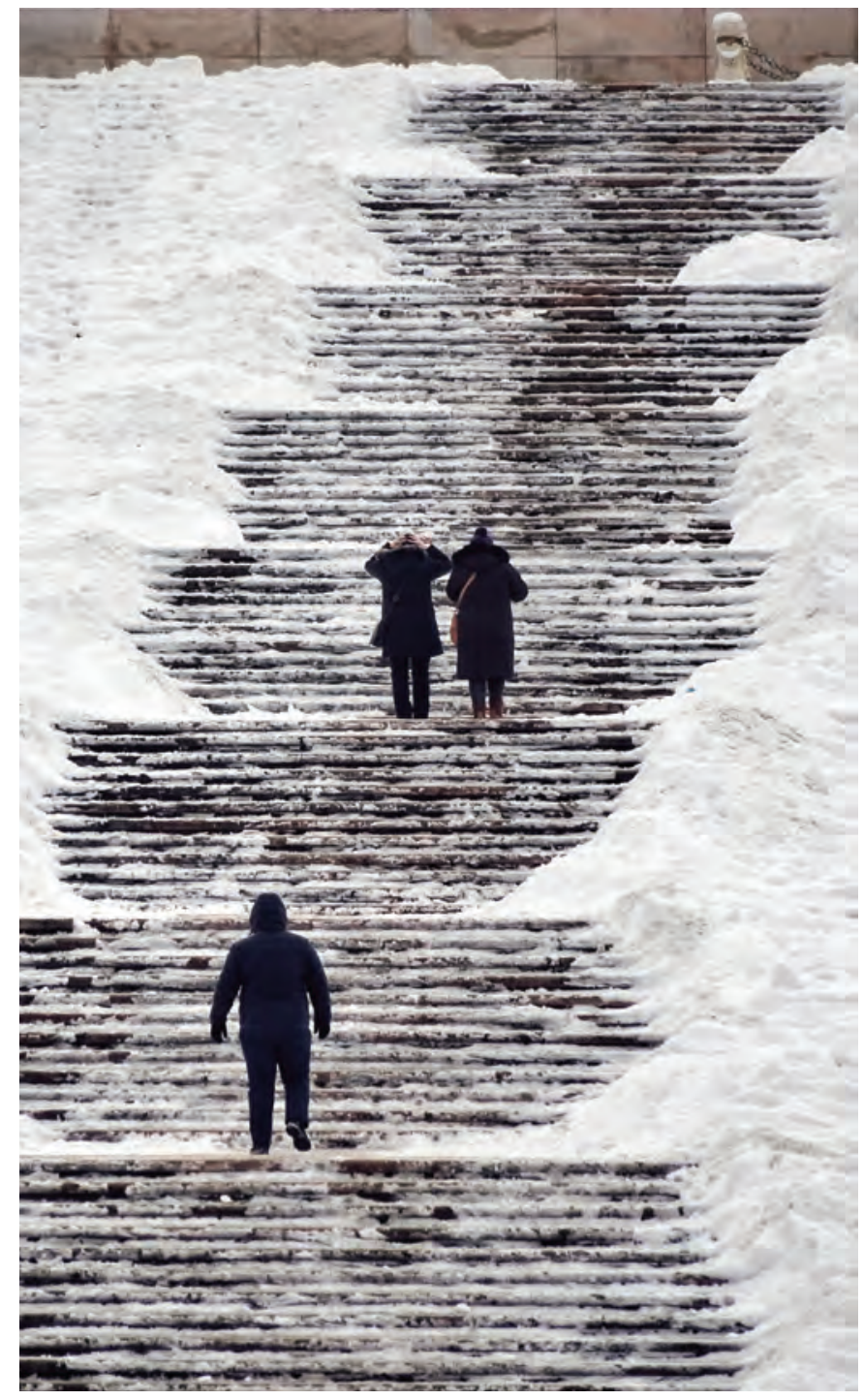


adesea cel mai anevoios prin natura provocărilor și pragurilor pe care le presupune.

Aici, însă, există de-a stânga și de-a dreapta alte două lumi. O lume a păsărilor, spre răsărit, a chiparoșilor de baltă înroșiti de toamnă, și o lume a culorilor calde de apus și a reflexiilor în oglinzi de ape calme, spre miazănoapte. Atunci când eroul ezită, iar ezitarea are rolul ei bine definit în poveste, se poate pierde pe alei lăturalnice.

Parcul Carol oferă cu dărnicie această alternativă, și chiar de la intrare. Sau ieșire, căci câteodată una se confundă cu cealaltă. Nicăieri nu scrie că drumul trebuie să fie simplu.

În mod neconvențional, cele două lumi sunt complementare și definesc spiritul acestui loc. Est și vest, opuse directiei nord-sud.

Sinuos și umbrit, opuse axului central, drept și transparent, expus intemperiilor și luminii soarelui. Definit și nedefinit, precis și atemporal, monumental și organic, tăcut și cu ecouri din alte lumi, cele două tărâmuri complementare definesc o lume complexă, încărcată de posibile semnificații și simboluri ascunse.

Descifrarea lor devine o provocare cu rol inițiatic. Pentru a se regăsi pe sine, eroul are nevoie să se piardă pe sine, înainte. Chiar și puțin.

Pentru a afla, trebuie să vrei să vezi. Ca să vezi, trebuie întâi să crezi.

La capătul traseului, în orice direcție o iei, e posibil să afli ceva nou despre sine. Pietonul adâncit în gânduri poate trezi ecourile uitate ale eroului care sălășluiește în adâncuri.

Dincolo de aparența unui parc liniștit, vegheat de silueta unui mausoleu destul de distant și rece, povestea poate începe de la orice pas, pentru că nimic nu e doar ceea ce pare, iar urmele și indiciile sunt atât de bogate aici, încât povestea începe să se țeasă de la sine, pas cu pas, pe măsură ce curiozitatea și imaginația creativă încep să deseneze lumi imaginare, acolo unde pare că lumea se termină la suprafața a ceea ce se vede.

Abia acum, din lungul aleii Parcului Carol, putem privi înapoi. Dacă ceva nou a apărut înlăuntru, chiar și o întrebare, nu neapărat un răspuns, înseamnă că a fost o plimbare bună. 


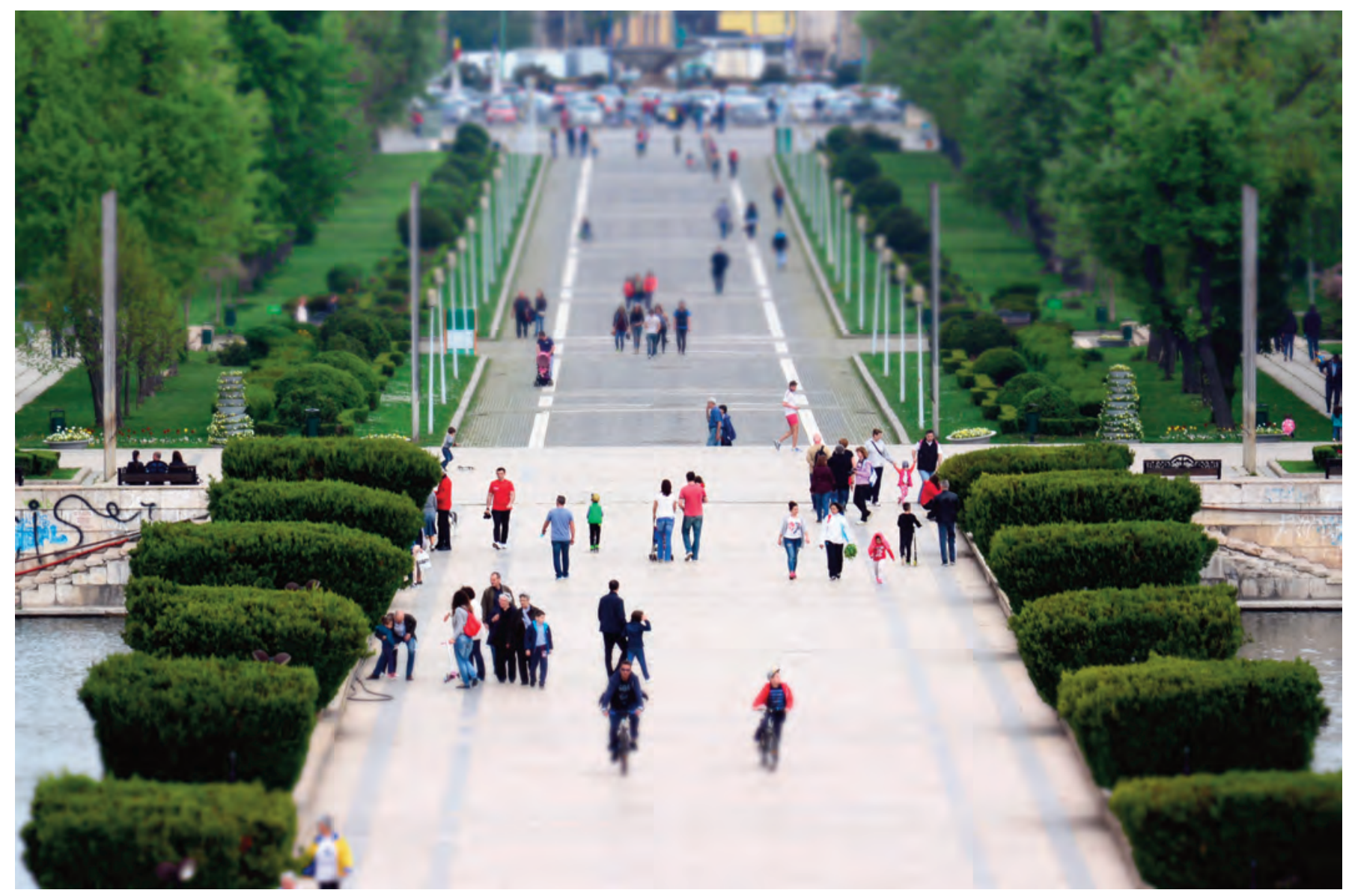

imaginile care însoțesc acest text reprezintă instantanee fotografice din Parcul Carol surprinse de către autor

\section{Vad EFTENIE}

este lect.dr. arh. al

UAUIM Bucuresti, fotograf profesionist 